\title{
REGULATION OF PHOTOSYNTHETIC CARBON FIXATION ON THE OCEAN MARGINS
}

\author{
Final Report of Grant \\ DE-FG05-93EREG199 \\ 61699
}

DOE/ER/61699-TI

DOE Ocean Margins Program

\author{
John H. Paul \\ University of South Florida \\ 140 Seventh Ave. S. \\ St. Petersburg, FL 33701 \\ (813) 553-1168
}

FAX: (813) 553-3966

\section{BACKGROUND}

The US Department of energy is concerned with the fate of energy-related materials (including $\mathrm{CO}_{2}$ ) in the marine environment. Regional studies along the US continental shelves have been supported by DOE, including the use of moored instrumentation, ship sampling/remote sensing, the study of the spatial and temporal concentration of chemical species, biological productivity, zooplankton grazing and respiration, ecological dynamics, and the biogeochemical flux of particles. In 1992, a plan was formulated for the study of carbon flux in the S. Atlantic Bight off Cape Hatteras. The objectives of this study were:

(1) Understand coastal marine biogeochemical processes and ecosystem dynamics. This objective strives to broadly understand how the coastal ocean acts as a system, as an interface between the continental land mass, estuaries, and the open ocean.

(2) Quantify carbon sources and sinks at the land/ocean interface. This objective has been broadly interpreted as defining the ocean margins as sources or sinks in global biogeochemical cycles.

(3) Determine whether coastal primary productivity is significant in removing atmospheric $\mathrm{CO}_{2}$. It is important to determine if the continental shelves are quantitatively significant in removing $\mathrm{CO}_{2}$ from the atmosphere and isolating it by burial on the shelves or transporting it into the interior ocean.

During FY 93 DOE launched a new molecular biology initiative, the goal of which was to provide a mechanistic understanding of the complex biological processes which mediate the carbon cycle in marine systems. Specific objectives of this subprogram were to:

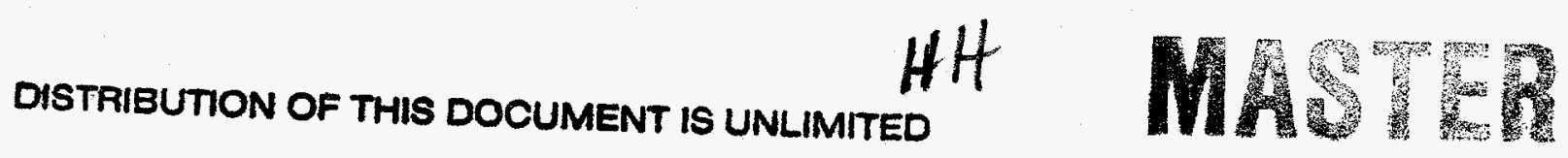




\section{DISCLAIMER}

This report was prepared as an account of work sponsored by an agency of the United States Government. Neither the United States Government nor any agency thereof, nor any of their employees, make any warranty, express or implied, or assumes any legal liability or responsibility for the accuracy, completeness, or usefulness of any information, apparatus, product, or process disclosed, or represents that its use would not infringe privately owned rights. Reference herein to any specific commercial product, process, or service by trade name, trademark, manufacturer, or otherwise does not necessarily constitute or imply its endorsement, recommendation, or favoring by the United States Government or any agency thereof. The views and opinions of authors expressed herein do not necessarily state or reflect those of the United States Government or any agency thereof. 


\section{DISCLAMMER}

Portions of this document may be illegible in electronic image products. Images are produced from the best available original document. 
1) Understand molecular regulation of photosynthetic carbon reduction. This succinctly describes the goals of our project.

2) Develop molecular diagnostic markers of bacterial growth, production, and nutrient limitations to growth.

3) Develop molecular techniques for elucidation of metabolic pathways.

Our project, entitled Molecular Regulation of $\mathrm{CO}_{2}$ fixation on the Ocean Margins, was principally directed at answering the first major objective of the DOE OMP program, and the first molecular objective described above. Our overall goal was two-fold, using both laboratory studies with isolates and field studies with natural populations. Our objectives were:

1. To determine the mechanism of regulation of ribulose-1,5-bisphosphate carboxylase/oxygenase (RuBPCase) in phytoplankton in response to changes in light fields.

2. To determine regulation of RuBPCase in response to light under nutrient deprivation.

Both of these objectives were to be performed in the laboratory of F. Robert Tabita, Co-PI, and will be discussed in the final report of his project. Our lab's objectives were:

3. To determine mechanisms of regulation of RuBPCase in natural populations of phytoplankton of the ocean margins using technology developed in objectives 1 and 2 .

4. To measure regulation of RuBPCase in phytoplankton of the Hatteras System.

\section{RESULTS AND FINDINGS}

Our field studies (Objectives 3 and 4 ) had four components to them: 1) The study of temporal variations in regulation of carbon fixation in natural populations. These studies investigated the possibility of diel regulation and entrained rhythms in RuBPCase gene expression, done in studies with Prochlorococcus Pacific strain in culture, deck-top incubations of natural populations, and in Lagrangian studies. The other components included: 2) The vertical distribution of RuBPCase gene expression in stratified water columns, 3) The size distribution of the phytoplankton responsible for carbon fixation by size fractionation studies, and 4) The molecular biodiversity of organisms involved in carbon fixation of the water column.

Temporal variation in the regulation of carbon fixation. Our hypothesis for this sub-area of 
the research was that phytoplankton constitutively expressed the RuBPCase gene ( $r b c L)$ throughout the day, and carbon fixation was controlled by light availability only. Alternatively, the gene could be transcribed in conjunction with the prime hours of sunlight for photosynthesis. To perform these studies mRNA was isolated from natural populations and probed with the $r b c L$ gene probe. In initial studies, the $r b c L$ gene from the cyanobacterium Synechococcus PCC6301 was used as a hybridization probe (cyano probe). This probe should hybridize to all cyanobacteria, green algae, and higher plants (Form IB RuBPCase). Because of molecular biodiversity in RuBPCase, in later studies we used an additional hybridization probe derived from Cylindrotheca species N1 (chromo probe). This probe should detect $r b c L$ expression in diatoms, prymnesiophytes, pelagophytes, cryptomonads, and other chromophytic algae. In early studies when only the cyano probe was used, a consistent pattern of diel regulation of $r b c L$ was found in cultures of Prochlorococcus, natural phytoplankton populations in deck-top incubators, or in natural populations followed in Lagrangian studies. RuBPCase gene expression was undetectable at night, and then "turned on" between 0600 and $0800 \mathrm{~h}$. The maximal peak was usually $1000 \mathrm{~h}$ but was noted as late as $1500 \mathrm{~h}$. The maximum in rbcl expression coincided with the time of the maximum in whole cell carbon fixation. When cultures or natural populations were incubated in continuous light, the same pattern of diel regulation was observed, indicative of endogenous rhythms in these organisms. These studies are summarized in the attached manuscript (Pichard et al., 1996) and were performed in the Gulf of Mexico.

When the chromo probe was used, a different pattern of regulation was observed. The chromo probe hybridized most strongly with samples taken in the late afternoon or early evening, usually lagging 6 to $8 \mathrm{hr}$ behind the peak in cyano $r b c L$ expression. This was demonstrated in the Cape Hatteras system on two cruises, the first in a decktop incubator study of water taken from the central mooring of the mooring array, and the second during a Lagrangian study during the RN Seward Johnson cruise of July, 1996. The latter was part of the DOE field experiment. Sampling occurred every $12 \mathrm{~h}$ between 0800 and 1000 and every evening between 1900 and $2100 \mathrm{~h}$. Cyano $r b c L$ expression was maximal during the morning sampling while chromo rbcL peaked during the evening sampling (Paul et al., in preparation). The chromo $r b c L$ peak undoubtedly was the result of diatom carbon fixation gene expression, as diatoms are major contributors to carbon cycling in these waters. These results for the first time demonstrate the temporal separation in the expression of carbon fixation genes between these two broad evolutionary groups of phytoplankton.

The vertical distribution of $r b c L$ gene expression in stratified water columns. These studies were aimed at deciphering the vertical distribution of evolutionary clades of phytoplankton in the water column, and were performed both in the Gulf of Mexico and in the Hatteras System. In both areas, maximal expression of cyano-like rbcL genes occurred in the upper water column $(0-60 \mathrm{~m})$ and correlated with Synechococcus and Prochlorococcus counts determined by flow cytometry. The base of the euphotic zone (68-100 m) was characterized by a peak in the chromo $r b c L$ hybridization that coincided with the 
subsurface chlorophyll a maximum (SCM) and picoeucaryotes as determined by flow cytometry. The picoeucaryotes included diatoms, prymnesiophytes and pelagophytes as determined by HPLC pigment analysis. In the DOE study site we also found a predominance of cyano rbcL mRNA in the upper water column $(0-10 \mathrm{~m})$ and a dominance of chromo rbcL, RNA (presumably diatoms) at the base of the water column ( $-35 \mathrm{~m}$ ). These results show that chromophytes, and diatoms in particular, are well adapted to carbon fixation in dimly lit subsurface waters, where they may participate in the removal of $\mathrm{CO}_{2}$ by sedimentation and burial on the shelves (Paul et al, in preparation).

The size distribution of autotrophs. In coastal waters, primary producers are generally larger in size than in offshore waters. Chromo rbcl expression was found in the $>5 \mu \mathrm{m}$ fraction while the cyano mRNA was found usually both in the $<1 \mu \mathrm{m}$ fraction and the $>5$ $\mu \mathrm{m}$ fraction. Cyano rbcL mRNA was exclusively found in the $<1 \mu \mathrm{m}$ fraction of offshore stations. These results indicate that these two evolutionary clades of carbon fixing organisms can be effectively separated by size fractionation. It is as if the niches for these organisms were separated by size.

The molecular biodiversity of organisms involved in carbon fixation in the water column. This area was not formally proposed in our project but we believe it is one of the most important issues in controlling carbon fixation on the continental margins. These studies looked at how genetically diverse the components involved in photosynthetic carbon fixation are in these environments. We have isolated the genes of carbon fixing organisms by two approaches: DNA amplification and RNA amplification (RT-PCR). The former should detect all organisms present (rather those hit with our PCR primers) while the latter determines the transcriptionally active phototrophs. Both approaches have met with success and our efforts yielded 8 such sequences. The results indicate that diversity of carbon fixers is great in the oceans and on the continental margins, because the 8 sequences obtained spanned the whole range of previously described RuBPCase sequences.

\section{APPLICATION TO DOE OMP OBJECTIVES}

As mentioned above, our results are particularly applicable to the first objective, to understand coastal marine biogeochemical processes and ecosystem dynamics. The diel regulation of RuBPCase in natural phytoplankton populations had not been known prior to our work. The fact that the two evolutionary clades (cyano and chromo) showed a temporal separation in expression was not known, either. That these large evolutionary groups were separated in expression of carbon fixation genes by cell size, position in the water column, and time of day was not known. When one studies carbon fixation, in a whole water sample, as a function of time of day, or at various depths in the water column, the result that is obtained is a one-dimensional picture of the carbon assimilation process. For example, in a whole water sample, a total net rate of carbon fixation, per volume of 
sample is obtained, without knowledge of the various components that contribute to this fixation. Size-fractionation has enabled us to ascertain that it is the result of picocyanobacteria and larger chromophytic eucaryotes. In fact, these two groups are apparently under different regulatory controls that may respond to different environmental stimuli. Thus, when one measures carbon fixation every hour during the day and finds one peak at midday, this is in fact the result of different groups of organisms which turn on and off their carbon fixation genes at different times of the day. When carbon fixation in the water column is measured and a broad peak occurs from 25 to $75 \mathrm{~m}$, this is in fact the net result of two different evolutionary groups, with procaryotes dominating the upper portion and chromophytic picoeucaryotes dominating the lower part of this peak. Working in concert, an impression is given that a homogeneous group of autotrophs are responsible for carbon fixation. Thus, our work has helped resolve the complexity of the fundamental biogeochemical process of photosynthetic carbon fixation on the continental margins.

The application of our results to the question of sources and sinks for $\mathrm{CO}_{2}$ on the continental margins or is burial and/or transport offshore of fixed carbon is this. When models are made to describe the carbon fixation process on the shelf and they are based only upon diatom fixation and biomass, such models will underestimate the true $\mathrm{CO}_{2}$ sequestering by the phytoplankton. They must include the smaller-sized picocyanobacteria which are abundant in the small size fractions and in the upper water column. If a vertical profile is measured to estimate carbon fixation in the water column and the time of day sampled is not given proper attention, the true rate of $\mathrm{CO}_{2}$ removal may be underestimated or overestimated, as differing phytoplankton groups express their carbon fixation genes at different times of the day. These results should be helpful in designing future field experiments and probing the vital question of the biogeochemical cycling of $\mathrm{CO}_{2}$ on the ocean's margins.

\section{PUBLICATIONS RESULTING FROM THE AWARD}

1. Pichard, S.L., M.E. Frischer, and J.H. Paul. 1993. Ribulose bisphosphate carboxylase gene expression in subtropical marine phytoplankton populations. Mar. Ecol. Progr. Ser. 101: 55-65. Repint-sepanate cycling

2. Paul, J.H. and S.L. Pichard. 1995. Extraction of DNA and RNA from Aquatic Environments. In: Nucleic Acids in the Environment: Methods and Applications, by J.T. Trevors and J.D. Van Elsas, ed., Springer-Verlag, pp 153-177.

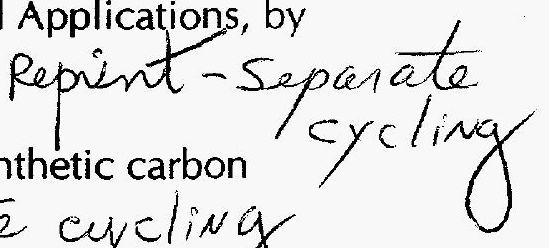

3. Paul, J.H. 1996. Carbon Cycling: Molecular regulation of photosynthetic carbon fixation. Microbial Ecology 32:231-245

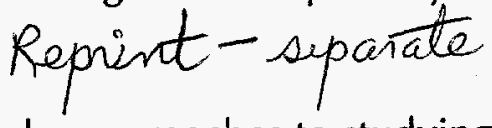
Paul, J.H. and S.L. Pichard. 1996. Molecular approaches to studying natural 
communities of autotrophs. In: M. Lidstrom and F.R. Tabita. Microbial Growth on C1 Compounds. pp. 301-309. Reprint

5. Pichard, S.L., J.B. Brown, L. Campbell, F.R. Tabita, and J.H. Paul. 1996. Regulation of ribulose bisphosphate carboxylase gene expression in natural phytoplankton communities. I) Diel rhythms. Marine Ecology Progress Series 139:257-265.

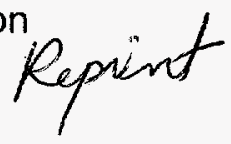

6. Pichard, S.L., L. Campbell, K. Carder, J.B. Kang, J. Patch, F.R. Tabita, and J.H. Paul.1997. Analysis of ribulose bisphosphate carboxylase gene expression in natural phytoplankton communities by group-specific gene probing. Mar. Ecol. Progr. Ser. (In press).

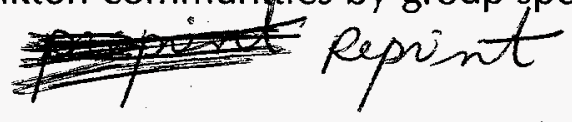

7. Pichard, S.L., L. campbell, and J.H. Paul. Diversity of Ribulose bisphosphate carboxylase/oxygenase form I gene $(r b c L)$ in natural phytoplankton communities. Submitted to Applied and Environmental Microbiology

8. Paul, J.H. and S. L. Pichard. Phytoplankton activity through the measurement of ribulose bisphosphate carboxylase gene expression [RuBisCO]. In. K. Cooksey, ed. Molecular Approaches to the Study of the Oceans. Chapman and Hall, in review.

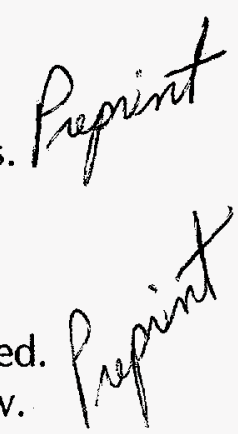

\section{STUDENTS SUPPORTED BY THE AWARD}

1. Scott L. Pichard, PhD student, is in the process of writing his dissertation and should graduate this summer.

2. Jordan Brown Kang, MS student, is in the midst of his thesis research. 